\title{
The institutional and political ontology of the firm
}

Helena Lopes

August 2020

WP n. ${ }^{\circ} 2020 / 03$

DOCUMENTO DE TRABALHO

WORKING PAPER

\author{
dinamia'cet
}

Centro de Estudos sobre a Mudanca

Socioeconómica e o Território

iscte

FCT

Fundação para a Ciência e a Tecnologia 


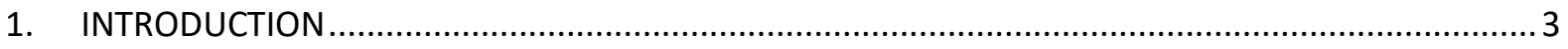

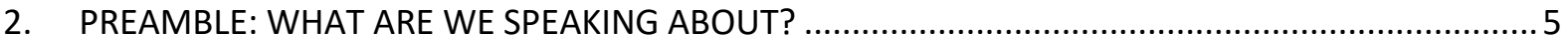

3. THE CRITICAL ISSUE: WHY ARE FIRMS MORE EFFICIENT THAN MARKETS? ................................ 6

4. THE TWO-TIERED INSTITUTIONAL ONTOLOGY OF THE FIRM ................................................. 10

5. OUTLINING A THEORY OF THE FIRM AND OF ITS POLITICAL NATURE ....................................... 15

6. NORMATIVE IMPLICATIONS FOR CORPORATE GOVERNANCE .............................................. 18

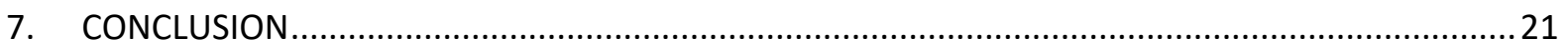

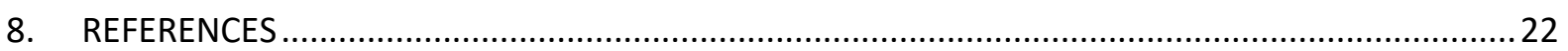




\title{
The institutional and political ontology of the firm
}

\begin{abstract}
:
The paper begins by specifying that it examines the institutional ontology of the firm, not only that of the corporation. It views firms as structured cooperative endeavors, emergent entities ontologically irreducible to their composing elements that exist by virtue of two distinct kinds of institutions: i) cooperative behavioral norms that emerge from interpersonal interactions between workers and account for horizontal cooperation, and ii) compliance with authority norms, related to the constitutive rules that ground organizational structures and account for vertical, subordinate, cooperation. The argument is that the deontic nature of these two institutions explains both firms' cohesiveness and efficiency, an argument that radically breaks with agency theory's denial of authority and individualistic ontology. A theory of the firm qua corporation (regarded as constituted by three parties - shareholders, workers and authority structures) as well as appropriate governance forms (industrial democracy, codetermination) are derived from the advanced ontological claims.
\end{abstract}

Key words: ontology of the firm; institutional ontology, theory of the firm, codetermination, constitutive rules, authority.

JEL classification: B52, D20, J50, J53, J83, 


\section{INTRODUCTION}

When in the real-world firms are going through a "great deformation" process because of shareholderoriented governance (Bower and Paine 2017; Favereau 2016), in the academic world economists seem to renounce providing a theory of the firm because of the difficulty of defining what a firm is in the first place (Hodgson 2019). Meanwhile, political sciences' disregard of the firm is increasingly denounced (Singer 2019); "political philosophy largely neglects the pervasiveness of authoritarian governance in our work lives and we should return our attention to it" (Anderson 2015: 96). That studies on the social ontology of firms emerge in such a context does not come as a surprise (Martins 2018; Deakin 2017; Lawson 2014; Chassagnon 2013; Gindis 2009); the need to investigate the nature and properties of firms is now pervading the whole relevant academic community. However, social ontology studies, though extremely stimulating, do not aim at theorizing the firm, which leaves the critical economic questions unanswered, namely why do firms exist, i.e. what makes them more efficient than markets? And how should they be governed? The present paper endeavors to answer these questions through an inquiry into the social ontology of the firm. Its main arguments are that i) the nature of the firm - what firms are - is basically institutional; namely firms exist thanks to two distinct kinds of institutions; ii) it is the interaction between these two kinds of institutions that allows the firm to function and thrive in market environments, ii) a specific mode of firm governance derives from the acknowledgment of this particular institutional ontology, a mode that breaks with shareholder primacy and advocates instead industrial democracy arrangements such as codetermination.

Being concentrated on the analysis of the institutions that constitute the firm and account for its efficiency, our ontological investigation works at a lower level of abstraction than the usual literature. Also, contrary to most ontological inquiry (Martins 2009), we aim at identifying ontological categories that can serve to construct a theory of the firm that "fits in with that existing in the real world" (Coase 1937: 403).

The key distinguishing feature of our argument is to relate the ontology of the firm to work specifically interactions at work. To our knowledge, an ontological link between the firm and work has never been established in the ontology of the firm literature. This parallels the economics literature in which work and the firm are apprehended by separate theories. Since we consider the firm as primarily a productive entity, requiring capital and workers who interact with assets and with one another, we see the firm as a collective endeavor rather than a collection of contracts or assets. This is critically contested within economics. Indeed, seeing firms as collectives of workers ${ }^{1}$ implies acknowledging the

\footnotetext{
1 "Workers" designates regular and temporary employees as well as individuals who work for the firm without benefitting from employment contracts - an expanding circumstance.

DINÂMIA'CET - Iscte, Centro de Estudos sobre a Mudança Socioeconómica e o Território Iscte- do Instituto Universitário de Lisboa Sala 2W4 - D | ISCTE-IUL - Av. das Forças Armadas 1649-026 Lisboa, PORTUGAL

Tel. (+351) 210464031 / 210464197 | E-mail: dinamia@iscte-iul.pt | www.dinamiacet.iscte-iul.pt
} 
need for organization and therefore conceiving firms as organized entities rather than nexus of contracts. Once acknowledged that firms are based on social interactions, the question arises as to which - kind of - institutions regulate and govern the different type of social interactions taking place within firms. Institutions are here defined as socially operative systems of rules, such as norms of behavior, characterized by their collective use (Hodgson 2019) in the regulation of social interactions. Firms are examined from a social ontology viewpoint to the extent that they would not exist apart from the interactions of human beings and that they exhibit properties that are specific to human interactions (see Dewey in Gindis 2009). Studying the institutions that underlie such interactions means inquiring the institutional ontology of the firm.

We assume that production in firms requires workers to behave cooperatively (not opportunistically) with one another and towards the organization, which leads to identifying two main kinds of institutions: those regulating interactions between workers, which we characterize as emerging from their capacity for sympathy; and those governing workers' behaviors towards the firm qua collective, which we characterize as related to authority, i.e. the organizational structure. Now, authority is the mark of the political, a normative device that enables people with divergent goals and beliefs to act nevertheless in concert (McMahon 1995). Collective action in firms emerges bottom-up but is also governed top-down by (coercive and non-coercive) power and social structuring, i.e. by the political. The acknowledgement of the second kind of institution implies recognizing that firms are political entities.

The paper is structured as follows. Given the lack of a shared taxonomic definition of the firm (Hodgson 2019), we begin by stating what we mean by "firm" and specifying the distinguishing traits of our approach (Section Two). In Section Three we argue that the efficiency of firms compared to markets depends on the ethical/deontic nature of the institutions that regulate workers' interactions; this account of the efficiency of firms is contrasted to that of the agency theory of the firm. Section Four characterizes the two kinds of institutions that form the ontology of the firm. Section Five derives a theory of the firm qua corporation from the advanced ontological claims and elaborates on the political nature of firms. Recommendations for corporate governance are derived from the firm's institutional ontology in Section Six and Section Seven concludes. 


\section{PREAMBLE: WHAT ARE WE SPEAKING ABOUT?}

The critical distinction to be made is obviously that between the firm (or enterprise), which designates an economic entity, and the corporation (or company), which designates a specific legal structure governing the firm. Corporations differ from firms "in that they are a) established as a separate and distinct legal entity and b) generally characterized by a three-tiered structure of shareholders, directors (elected by the shareholders for overseeing the broad goals and directions of the company), and officers (elected by the directors to run the day-to-day operations of the business)" (Singer 2019: 5) ${ }^{2}$. The object of the ontological inquiry of the present paper is the firm, i.e. the productive, business, economic entity. Firms thus conceived exist separately from the legal rules governing them (this is not to say that the firm's legal form has no effect on its functioning); business may be conducted under a variety of legal forms, including partnerships, sole proprietorship and corporation. It is worth noting that our perspective departs from agency and property rights theories of the firm which implicitly equate the corporation and the firm (Weinstein 2012). This led agency theorists to concentrate on the relationship between shareholders and managers and disregard work and workers. Since the present paper is concerned with the ontology of the firm, not the corporation, the latter enters our reflection only in the last sections, when addressing governance issues.

Thus, our inquiry, contrary to most social ontology studies of the firm/corporation (Deakin 2017; Lawson 2014; Chassagnon 2013; Gindis 2009), does not delve into the role of the legal status of the firm. However, it does consider one element that pertains to the legal structuring of business firms, namely employment law and the employment contract. This is coherent with our ontological approach of the firm, which relates it with work. By contrast, corporate law, which is the element of the firm's legal structuring most addressed by social ontology studies, concentrates on the relations between shareholders and managers and only rarely considers the relationships between the firm and workers (Greenfield 1998). Focusing on firms as productive entities and consequently giving work central stage ${ }^{3}$ requires considering employment law, which provides the formal institutional shaping of work. In fact, employment law played a major historical role in the emergence of firms as hierarchically structured organizations and it contributed to the establishment of industrial relations systems (Didry 2019). Our object of study is hence the firm as it historically appeared at the end of the 19th century. This approach

\footnotetext{
2 Note that shareholders do not own the corporation, much less the firm; they only own their shares of the corporation. The firm's productive assets are owned by the corporation, not shareholders (Singer 2019; Favereau 2016 , 2018). Likewise, it is the corporation, not shareholders, that establishes contracts of employment and is then bound by them.

3 Conversely, and importantly, the terms "work" and "workers" are not mentioned in Jensen and Meckling (1976) and Fama (1980) papers on the firm nor in Lawson (2014) and Gindis (2009)'s social ontology studies. The term "employee" only appears in passing once or twice.
}

DINÂMIA'CET - Iscte, Centro de Estudos sobre a Mudança Socioeconómica e o Território Iscte- do Instituto Universitário de Lisboa Sala 2W4 - D | ISCTE-IUL - Av. das Forças Armadas 1649-026 Lisboa, PORTUGAL

Tel. (+351) 210464031 / 210464197 | E-mail: dinamia@iscte-iul.pt | www.dinamiacet.iscte-iul.pt 
follows Coase (1937) who states that a theory concerned with real-world firms should look not at corporate law but at employment law. We also follow Coase in considering that the question of the nature of the firm (of the firm's ontology) is intimately linked to the reasons why firms exist, i.e. to the question of firm's efficiency relative to markets.

\section{THE CRITICAL ISSUE: WHY ARE FIRMS MORE EFFICIENT THAN} MARKETS?

\section{Recalling mainstream accounts of the firm's efficiency}

Coase (1937) was the first mainstream economist to inquire why firms exist in the first place. His famous answer is that there are costs of using the (market) price mechanism, costs related to discovering the relevant prices and negotiating contracts; these costs can be reduced by replacing the market structure by an entrepreneur coordinator, thus substituting a few contracts of employment for a multitude of contracts for services. It is the entrepreneur's ability to direct the factors of production and be obeyed by employees that renders the firm more efficient than markets. That is, organizational coordination is more efficient than market coordination when organizational structures secure obedience and compliance with orders. Authority is therefore what defines a firm, regarded as an employer, and what distinguishes it from the market.

Thirty-five years later, Alchian and Demsetz advanced an anti-Coasian rationale ${ }^{4}$ for the existence of firms, one that asserts that "the firm and the ordinary market" are only "competing types of markets" (Alchian and Demsetz 1972: 795). This assertion rests on the denial of authority, i.e. the specificity of the employment contract: "The employee 'orders' the owner [of the firm] to pay him money in the same sense that the employer directs the team member to perform certain acts. [...] 'Authoritarian' or 'fiat' attributes [are not] relevant to the conception of the firm or its efficiency" (Alchian and Demsetz 1972: 783). Jensen and Meckling (1976) go further in this understanding of the firm by seeing team production as the exception rather than the rule (thus discarding the collective character of work and production) and defining the firm as a "nexus of contracts". Since contracts are regarded as agreements freely entered into by the contracting parties, the firm is nothing more than a voluntary coalition of individuals, a collection of contracts between owners of different productive resources. Hence the famous assertion that firms are legal fictions that serve as recipients for contracts

\footnotetext{
4 This strand of literature epitomizes a reaction not only to Coase (1937) but also to Berle and Means' theorization of the firm. Based on Coase (1960) and more broadly on the reaffirmation of contractual freedom and free market as the founding principles of social order, it is part of a liberal and intellectual project (Singer, 2019; Weinstein, 2012) we return to later.
}

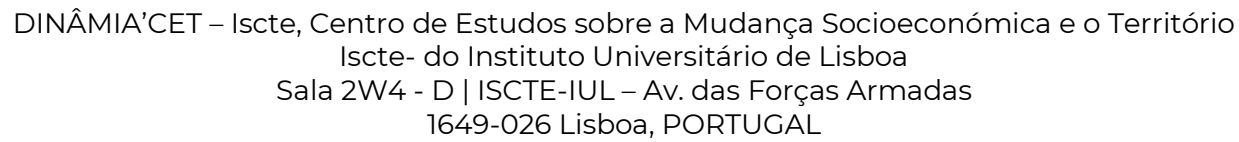


between individuals pursuing their own interests. "The firm is just the set of contracts covering the way inputs are joined to create outputs" (Fama 1980: 290).

It is important being aware that it is the denial of the specificity of the employment contract that lies at the core of two major interrelated agency theory's claims. The first claim is that the firm is not an employer in the way stipulated by employment law. In rigor, neither the term employee nor employer should be used by agency theorists since, as referred, according to them employment contracts do not differ in nature from other contractual arrangements. In agency theory, employment contracts authority relationships - are replaced by principal-agent contracts, defined by the delegation of some decision-making "authority" by principals to agents. But the term "authority" in this definition means "scope of discretion" and does not refer to the subordination relationship invoked by Coase (XXX 2020). Quite on the contrary, the way in which principal-agent relationships are conceived insinuates that principals are at the mercy of agents' opportunism rather than agents being at the mercy of principals' directives. ${ }^{5}$ Jensen and Meckling (1976) concentrated on the relationship between shareholders as principals and managers as agents but subsequent literature extended the notion to the relations between supervisors as principals and workers as agents.

The second claim is that it is not an organizational structure grounded on authority that makes firms efficient. Agency theory's vision of the firm is encapsulated in principal-agent relationships: no organizational structure is needed to manage this kind of relationships because the only reason for conflict is opportunism, on the part of agents towards principals, and this conflict can be solved by adequately designed incentive pay structures (Rebitzer and Taylor 2011). The benefits of price/market mechanisms extend to relations within firms; markets for securities and labor complement incentive schemes in inciting agents to behave appropriately. The efficiency of the firm is thus just an extension of the kind of efficiency achieved by markets - now seen through the lens of the contractual paradigm - and does not differ in nature. Like in markets, the efficiency of firms relies on people following selfinterested and competitive behavioral norms.

Hart (1989) points out that neither Coase nor agency theory explains how contractual failures are mitigated. Coase clearly understood that the employment contract involves a set of rights and obligations different from those of a market transaction but he took obedience for granted without further scrutiny. Agency theorists, in turn, assume that adequate contractual arrangements solve opportunism. But self-interested employers and employees cannot be trusted to keep their word because the contracts they establish are incomplete, which makes their contractual commitments unenforceable

\footnotetext{
${ }^{5}$ Anderson (2015) denounces this denial of the real-world fact that workers lie under the authority of their bosses; in her view, positing that individual choice and contractual freedom is what grounds the firm amounts to cultivating the illusion of workers' freedom and equality and does not account for the existence of firms. 
by courts. Hart then advances an alternative explanation: "The reason that an employee is (...) responsive to what the employer wants (...) is that the employer can deprive the employee of the assets he works with" (Hart 1989: 1771). It is fear and power rather than freely negotiated contracts that grant obedience. This reasoning leads Hart and colleagues to propose the property rights theory, which defines the firm as the collection of assets it owns; ownership of physical assets in turn confers the power to exercise control over human assets. Whilst based on a different argument, "human assets" or work/workers are, like in agency theory, kept out of the definition of the firm. Which is the opposite of the main contention of the present paper.

The critical question is raised by Hart (Gindis 2009): what is the glue that keeps the firm together? What makes a collection of contracts hold together and form a functioning whole? The response is: a firm is more than the aggregation or collection of elements; it is a collective of people.

\section{The collective and cooperative nature of the firm}

In Coase (1937: 393)'s terms, "A firm consists of the system of relationships which comes into existence when the direction of resources is dependent on an entrepreneur", and he later emphasizes that only when "several contracts of employment are made with people and for things which cooperate with one another that you get the full firm relationship".

The first, pivotal, step of our ontological inquiry consists in arguing that firms are constituted by the acting in concert of actors whose interactions are cooperative and directed by an entrepreneur (authority). We see production as a collective action endeavor that requires engaging a cooperating collective rather than a collection of persons ${ }^{6}$. The more complex and innovative the productive activities, the higher is the requirement for cooperative interactions between firm members (Grandori 2016). To create the cooperation required to achieve productive goals, firms build organizational structures, which involves delineating responsibilities and "the existence of social roles or positions that have properties irreducible to those who occupy them." (Hodgson 2019: 226). In firms, these roles/positions embody authority, whose exercise is required to coordinate production and ensure cooperation.

This view of the firm comprises two related contentions: $i)$ stating that the firm is a cooperative venture means that it is not reducible to its individual members, it is a distinct "re(lation)al" entity (Singer 2018) entity; ii) stating that cooperative productive ventures require organized coordination means that decision-making procedures and hierarchical roles need be instituted. That is, firms qua structured cooperative endeavors are social phenomena that exist by virtue of the behavioral rules

\footnotetext{
6 This is why digital platform work does raise severe challenges to the theory of the firm, and consequently to firms' and workers' legal status.

DINÂMIA'CET - Iscte, Centro de Estudos sobre a Mudança Socioeconómica e o Território Iscte- do Instituto Universitário de Lisboa Sala 2W4 - D | ISCTE-IUL - Av. das Forças Armadas 1649-026 Lisboa, PORTUGAL

Tel. (+351) 210464031 / 210464197 | E-mail: dinamia@iscte-iul.pt | www.dinamiacet.iscte-iul.pt
} 
followed by and roles assigned to its members. Firms are thus entities qualitatively different from the aggregation of their parts; cooperation is an emergent phenomenon ontologically irreducible to its preexisting elements (Lawson 2014).

Put in social ontology terms, the two key features of firms thus viewed are that i) something "other and above" emerge from the interactions between individuals and ii) individuals are linked and bound by constitutive rules that create "deontic powers", i.e. rights and obligations. These two features comprise two distinct types of institutions which we argue constitute the institutional ontology of the firm. We name ICoop the Institutions/Cooperative norms that emerge from interactions between peers and IAuth the Institutions/compliance-with-Authority norms, related to constitutive rules, that characterize the interactions between individual members and the organizational structure.

Cooperative behavioral rules (ICoop) are ontologically irreducible to, albeit emergent from and dependent upon, human interactions; i.e. even though cooperative rules and human agency are interdependent, they are distinct modes of social beings (Martins 2009). In turn, IAuth are special instances of what John Dewey calls constitutive rules, i.e. rules that enable the creation of a deontology of rights and obligations (Martins 2018; Gindis 2009): IAuth is both an emergent and an instituted phenomenon (see below). The deontic power of constitutive rules stems from it being formally recognized and instituted by an official agency; this is what organizational structures do when delineating responsibilities and assigning functions to persons or services. Indeed, by shaping decisionmaking power, authority gives an organization its formal structure. Authority's deontic power is importantly backed by employment law, which institutes and reinforces vertical relationships within organizations.

The second step of our ontological inquiry consists in showing, in the next section, that firms produce goods and services more efficiently than the price mechanism thanks to the two kind of institutions just outlined - which is a further argument for their being the firm's institutional ontology. ICoop and IAuth are the source of a type of efficiency, named "norm-governed productivity" by Singer (2019), that can be generated within organizational structures but not within the "privately owned markets" depicted by Alchian and Demsetz (1972: 795). These two kinds of institutions are, importantly and expressly, absent from mainstream economics' analytical framework because of the individualistic, and axiologically neutral, ontology on which mainstream theoretical venture relies and without which it would collapse. As for ICoop, behavioral economics does acknowledge that economic agents are also driven by cooperative preferences, but in behavioral models cooperation, rather than emerging from social interactions, results from decisions taken separately by each worker depending on her/his preferences (Non 2012), In turn, authority as a subordination relationship, resulting from bilateral relationships or organizational structure, is explicitly and definitely denied, as referred. For agency 
theory, humans live in a structure of property and contracting rights, not in work collectives, and their behavior is strictly governed by incentives. Any term "which carries with it some unfortunate moral connotations [is] of no aid to positive analysis" (Jensen and Meckling 1979: 502).

\section{THE TWO-TIERED INSTITUTIONAL ONTOLOGY OF THE FIRM}

The aim hereafter is to scrutinize the institutions that help explain horizontal (ICoop) and vertical (IAuth) cooperation within firms. In productive collective and hierarchical endeavors, workers engage in two kinds of interactions: they interact as particular individuals in horizontal interpersonal relationships, and they interact as members of a collective with authority persons or rules whose mandate is to regulate the collective, in an asymmetrical, vertical relationship. Our argument is that these two types of cooperation are grounded on two distinct kind of ethics (Lopes 2018; Graham et al 2011): the "ethics of autonomy" that relies on concepts such as care, justice, equality and is individualbased, and the "ethics of community" that relies on concepts such as duty, authority, interdependency and is group-based (Shweder et al 1997: 138-139). The ethics of community has "binding foundations"; it is about binding people together into large groups to preserve social order. These two types of ethical dispositions can be viewed as belonging to Searle's "Background Dispositions". Western intellectual history and societies have so far privileged the ethics of autonomy.

\section{The roots of cooperative norms (ICoop): sympathy}

In The Theory of Moral Sentiments, Adam Smith (1759) forged the concept of sympathy to explain complex social phenomena such as practices of morality and social order. For Smith, social phenomena are to be understood as emergent properties of interactions between individuals: the interpersonal relations into which individuals enter generate affective states that help emerge and sustain norms of cooperation. The basic psychological assumption is that individuals have a capacity to feel imaginatively the experience of others and so to share their pleasures and pains; this leads to a "correspondence of sentiments". This correspondence of affective states is in turn the basis for judgments of approval or disapproval of own's and others' actions. The whole process thus involves both cognitive (judgmental) and affective elements and, importantly, it is largely unconscious and thus hardly apt to any kind of calculation. Sugden (2005) points out that affective states are not preferences - i.e. objective options that can be compared to one another - but instead subjective experiences of the 
world. Since affective states are neither preferences nor beliefs, they do not fit into mainstream economics' ontological framework ${ }^{7}$.

Sympathy, now most commonly referred to as empathy in the relevant literature, has seen renewed interest among psychologists and neuroscientists since the 2000s. The ubiquitous reference to Adam Smith is striking; it is as though not much has been discovered about the psychological processes underlying empathy other than their neurological - mirror neurons - or neurobiological - oxitocyn substrates (Rizzolatti and Craighero 2005; Zak and Barraza 2013, respectively). Collective action, i.e. behaviors that are performed with others to meet a goal or reach a desired outcome, and empathy are driven by the same physiological drivers; this is why empathy promotes cooperation (Zak and Barraza, 2013). It is also shown that individuals are often self-concerned and other-orientated at the same time (Bolino and Grant 2016). Adam Smith was right: sympathy does appear to be the basis for moral behavior and cooperation.

Our claim is that this is what occurs when individuals work together: workers, through their recurrent interactions while participating in collective production, adapt their sentiments to those of others and tend therefore to converge on common behavioral norms (XXX, 2020). (Processes of affective dissonance and the corresponding judgments of disapproval may, of course, lead to severe disruptive events and breaks in cooperation. The common behavioral norms on which workers converge are not always good or prosocial. Besides, the willingness to cooperate declines as social ties become more distant). These norms are ICoop, the inter-individual-level institutions regulating behavior that explain "horizontal" cooperation. They contribute to explain the firm's efficiency to the extent that cooperation and sharing are shown to be decisive for organizational efficiency, for example and in particular in knowledge intensive and innovation contexts (Grandori 2016). Put in ethics of autonomy terms, they explain why workers feel like cooperating (i.e. express care, reciprocity, respect) rather than free-riding on others' productive efforts and why they expect others not to behave opportunistically either. The "lower-level" (Lawson, 2012) behavioral rules originating from people's ability for sympathy are what explain the "higher-level", emergent, cooperation phenomenon.

Sympathetic dispositions do not, however, explain why workers comply with authority's directives. Authority is a "vertical", supra-individual and asymmetrical, phenomenon, very different in nature from interpersonal interactions. It raises the fundamental question formulated by Raz (2006: 1012): "how can it ever be that one has a duty to subject one's will and judgment to those of another?"

\footnotetext{
${ }^{7}$ Foss and Stea (2014: 104) provide a singular attempt to incorporate the "ability to put oneself in another person's shoes" (sympathy) into agency theory. But the authors emphasize that only the cognitive part of such ability is relevant for their purpose - which is to explain principals' ability to coordinate, not firm members' ability to cooperate. The affective and motivational processes underlying sympathy are expressly set aside, which means expelling the axiological dimension of interpersonal relations.
}

DINÂMIA'CET - Iscte, Centro de Estudos sobre a Mudança Socioeconómica e o Território Iscte- do Instituto Universitário de Lisboa Sala 2W4 - D | ISCTE-IUL - Av. das Forças Armadas 1649-026 Lisboa, PORTUGAL

Tel. (+351) 210464031 / 210464197 | E-mail: dinamia@iscte-iul.pt | www.dinamiacet.iscte-iul.pt 


\section{The firm's major constitutive rule: authority}

For a collective of work to act in concert towards a common goal, social roles must be assigned to individuals such that some individuals take decisions that are to be carried out by other individuals. Authority is a form of directive power without coercion, meaning that authority, unlike coercive power ${ }^{8}$, requires acceptance, or consent (XXX 2020). McMahon (1994), who applies Raz (2006)'s analysis of political authority to the managerial sphere, provides a very compelling account of managerial authority: authority is defined as a collective institutional arrangement, the justification of which is that it facilitates mutually beneficial cooperation among people with divergent aims. For McMahon, authority is based on a particular cognitive mechanism: subordinates take the authority's directives as preemptive reasons for acting, i.e. accepting authority involves excluding certain reasons for action from consideration, including one's own reasons. Individuals as subordinates suspend their judgments, which are replaced by the authority's directive. For McMahon, the threat of being fired, the fact that one is paid, or the legal duty to comply with the employer's orders are not the kind of reasons that can justify obeying managers' authority. Managerial authority is justified by, derives from, the fact that management facilitates mutually beneficial cooperation among individuals with divergent aims and beliefs. When individuals think they can produce a state of affairs that is better for everyone, including themselves, by acting together, they accept subordination and obey directives.

The cooperative behavioral rules emerging from the ability for sympathy (ICoop) within firms are "regulative rules" in Searle's terminology, because of their strong self-enforcing character. By contrast, authority (IAuth) pertains to the class of "constitutive rules" that "not only regulate but rather constitute the very behavior they regulate", and are defined by the following formula: " $X$ counts as $Y$ in $C^{\prime \prime}$ (Guarnieri 2018, 1,2, citing Searle). A constitutive rule exists when a group collectively recognizes that a certain entity, person or state of affairs $X$ possesses a given status function $Y$ in a given context $C$. Transposed to firms, $\mathrm{X}$ is the person or impersonal entity that possesses authority (status functions), i.e., a deontology of rights and obligations - deontic powers in Searle's terminology - in the firm's organizational structure. The collective acceptance of managerial authority derives, in the perspective adopted here, from authority facilitating cooperation. Authority is effective "only in virtue of collective recognition by the community that the object or person has the requisite status. [...] deontic powers provide people within institutions with desire-independent reasons for action" (Guarnieri 2018: 3,4, citing Searle). These assertions are in line with the definition and characterization of authority advanced above: complying with authority's directives implies suspending one's personal reasons for action.

\footnotetext{
8 We are obviously aware that, besides authority, power under the form of coercion does pervade work environments. We nonetheless only examine the authority phenomenon here.

DINÂMIA'CET - Iscte, Centro de Estudos sobre a Mudança Socioeconómica e o Território Iscte- do Instituto Universitário de Lisboa Sala 2W4 - D | ISCTE-IUL - Av. das Forças Armadas 1649-026 Lisboa, PORTUGAL

Tel. (+351) 210464031 / 210464197 | E-mail: dinamia@iscte-iul.pt | www.dinamiacet.iscte-iul.pt
} 
The reasons why workers accept the roles assigned to them by the structured institutional arrangement and accept authority's directives needs, however, further scrutiny. McMahon (1994) invokes collective rationality to explain acceptance of managerial authority and renunciation to free riding. In his view, only collective rationality can explain that workers suspend their judgement in the benefice of unity of action, thus enabling the full realization of the benefits of cooperation. In a similar vein, the social ontology literature considers that collective intentionality is a condition required for people to follow behavioral rules. People accept the roles they have been assigned and comply with associate behavior (they follow IAuth) because "individual intentionality $[. .$.$] derives from the collective intentionality$ that they share" (Searle 1995: 24-25). But these explanations overlook a serious issue: collective rationality, team reasoning or collective intentionality models do not, in our view, duly distinguish between "horizontal" and "vertical" cooperative phenomena. Managerial authority is a collective phenomenon in which a group of people subject their will and judgment to those of another: there is a transfer of power from many people to one. Such transfer is indeed collectively accepted but the "verticality" that characterizes authority within firms involves subordination, which is no trivial phenomenon (this is why it is backed by employment law: convergent but also antagonistic interests are at stake). The function and responsibility of managers is not to pursue each member's interest but to pursue the goals of the organization, which is a kind of "supra-individual" common interest reachable only through the exercise of directive (though non-coercive) power. Authority results from bottom-up phenomena - recognition and acceptance of status functions by each member - and top-down, instituted, design.

Martins (2018: 84) distinguishes between two different ontological phenomena: collective phenomena, whose key organizing principle is collective intentionality, and institutional phenomena, whose key organizing principle is constitutive rules. In our framework, ICoop pertains to the former while IAuth pertains to the latter. ICoop are instances of collective intentionality to the extent that they refer to the ability for sharing mental states; the ICoop norms generated by social interactions between workers enable a type of cooperation (horizontal) in firms that does not require organizational identity or internalization of the firm's mission. Martins is right when contending that leadership, which he connects to collective phenomena and regulative rules, differs from deontic power, connected to institutional phenomena. Conversely, IAuth compliance norms are instances of deontic power pertaining to institutional phenomena in that they presuppose an enduring and instituted set of roles and functions, i.e. constitutive rules. People in charge of authority may be leaders ${ }^{9}-$ this certainly helps

\footnotetext{
${ }^{9}$ Leadership tends to make critical judgment disappear and is thus different in nature from authority, which is a subordinating phenomenon in which subordinates suspend but do not abdicate from divergent judgements (Raz 2006; McMahon 1994).

DINÂMIA'CET - Iscte, Centro de Estudos sobre a Mudança Socioeconómica e o Território Iscte- do Instituto Universitário de Lisboa Sala 2W4 - D | ISCTE-IUL - Av. das Forças Armadas 1649-026 Lisboa, PORTUGAL

Tel. (+351) 210464031 / 210464197 | E-mail: dinamia@iscte-iul.pt | www.dinamiacet.iscte-iul.pt
} 
them perform their role - but authority is instituted by constitutive rules, which are not reducible to regulative rules. IAuth embody a vertical type of cooperation. The relationship between the individual and the collective of work, which is inevitably mediated by the exercise of authority for the collective productive purpose to be reached, involves the ethics of community, a set of rights and obligations essentially different from that of the ethics of autonomy in that it goes beyond individualistic ontology. Our point is that IAuth - and institutional phenomena grounded on constitutive rules more broadly - call for a group-based ethics and cannot be accounted for by referring solely to individual-based ethical norms. These two types of cooperation and ethics are improperly, in our view, subsumed into the notion of collective intentionality.

Workers follow IAuth norms because they acquiesce contributing in the collective productive purpose. This does not imply that workers identify with the firm but only that they voluntarily engage in the productive endeavor; their relationship with the firm, peers and superiors may be centered on their relationship to their work, not necessarily the firm. Notwithstanding, even so, since work in firms is a collective endeavor, every worker comes to be embedded in a network of reciprocal rights and obligations and, because every human has ethics-of-community's dispositions, she accepts more or less consciously being bound by the organizational structure.

To sum up, our account of the firm's efficiency sees it as resulting from the interaction of bottom-up and top-down phenomena, making room for agency as well as recognizing the role of organizational structure. The response to Raz's question involves the workers' capacity for sympathy as well as their community-based ethics activated by their involvement in a structured collective productive venture. ICoop and IAuth form the institutional ontology of the firm because without them the firm would not be an emergent, ontologically distinct entity and firms would not have sources of efficiency distinct from that of markets.

Now, the acknowledgement of IAuth raises two major critical concerns that agency theory and the liberal political project that it epitomizes - wants to discard. Firstly, the foregoing developments concentrated on why people accept authority, but it is now time to examine what is required from those who exercise authority: responsibility and accountability are required. It is documented by anthropologists that in all human communities authority always comes with a responsibility counterpart; this is part of the ethics of community (Graham et al 2011; Shweder et al 1997). Deontic powers in social ontology are indeed assigned rights and also obligations. Secondly, we are all aware of the dark side of authority - it may and did/does give rise to awful dictatorships and voluntary servitude - which occurs precisely because of people's dispositions to accept authority. The response to this fact is not to deny it but rather to take it seriously and confront it; in firms, IAuth compliance norms may be used to exploit and manipulate workers. Appropriate institutional arrangements are hence called for to make 
authority legitimate and reliable - which is precisely what agency theory tries to avoid when denying authority and when downplaying the firm as employer.

\section{OUTLINING A THEORY OF THE FIRM AND OF ITS POLITICAL NATURE}

\section{A theory of the firm qua corporation}

The concerns just mentioned could suffice to suggest proper governance forms, but the latter can also be derived, analytically rather than solely normatively, from the ontological claims advanced above. Whilst an inquiry on the firm's institutional ontology requires distinguishing the firm's economic purpose from its legal status, the legal form of the firm must be considered when it comes to governance issues. Indeed, not one economic entity exists without legal status and it is the latter, i.e. whether the economic entity takes the legal form of cooperative, partnership, corporation, etc, that shapes its mode of governance. In fact, confusing the firm and the corporation from the outset, as in mainstream theories of the firm, amounts to confound the positive with the normative and consequently unduly naturalizes the governance mode drawn from such theories.

Hereafter we derive from our ontological claims a theory of the incorporated firm, i.e. of corporations. The latter are regulated by corporate law, whose content in all jurisdictions is currently influenced by agency theory, its finance-based approach and its principal-agent paradigm (Bodie 2012; Armour 2005). According to Jensen and Meckling (1979; 1976) and Fama (1980), the most efficient governance system for firms/corporations is to give shareholders the right to control the actions of directors/managers because it is shareholders who are supposed to bear the greatest investment risk. Shareholders are thus the principals and directors/managers are their agents. These are the two parties that constitute corporations in corporate law, whose aim is to regulate the relationship between shareholders and managers. This perspective results in the following governance traits: i) the primary purpose of corporate governance is to ensure that directors/managers act in the interest of shareholders (shareholder-oriented governance) and ii) workers and their interests are excluded from corporate law and practices. All this in the name of economic efficiency. "Both boardrooms and courts have taken the normative call for shareholder value maximization increasingly at heart" (Bodie 2012: 1033).

Shareholder-oriented governance primarily focusses on financial transactions and targets, leaving corporate law disconnected from the strategic and operating management of the firm (Bodie 2012; Greenfield 1998). In fact, separation between capital and management is a founding principle of corporate law, which prevents shareholders from interfering in management affairs and participating in productive activities (this is why they are not included in our ontological inquiry).

\footnotetext{
DINÂMIA'CET - Iscte, Centro de Estudos sobre a Mudança Socioeconómica e o Território Iscte- do Instituto Universitário de Lisboa Sala 2W4 - D | ISCTE-IUL - Av. das Forças Armadas 1649-026 Lisboa, PORTUGAL

Tel. (+351) 210464031 / 210464197 | E-mail: dinamia@iscte-iul.pt | www.dinamiacet.iscte-iul.pt
} 
The aim of the present paper is precisely to reintroduce in the theory of the firm what agency theory discarded, namely the productive structure, which relies on work and workers, as argued in the institutional ontology claims above. Dealing now with incorporated firms, shareholders must be included in the analysis. Our theory of incorporated firms understands them as being constituted by three parties (Favereau 2018): i) shareholders, who provide capital; ii) authority as a structured institutional arrangement that organizes production (authority can be exercised personally by managers or through the setting of rules and procedures); iii) workers, who supply work. Authority, i.e. the organizational structure, embodies the collective productive purpose, i.e. the interest that is common to the three parties. This is in line with Marshall (1890)'s insight that organization should be recognized as a distinct agent of production. Workers are subordinate not to shareholders - with whom they never interact - but to the collective of production, i.e. a set of persons involved in a common productive purpose whose interactions are bounded by specific institutions. It is worth specifying that workers feel a duty to comply with authority's directives because these embody the collective purpose; they assuredly have/feel no duty towards shareholders.

Before examining the implications on governance of this three-constitutive-parties theory of the incorporated firm, the empirical evidence that is accumulating on the effects of current corporate practices must be briefly mentioned. In 2000, Hansmann and Kraakman claimed "the end of history for corporate law", noting that although the shareholder-oriented model only originated in the 1980s, the observed uniformity across jurisdictions, the convergence toward a single corporate law model, and the consensus among academic, business, governmental and legal elites, were indisputable signs that this mode of corporate governance had definitely outplayed alternative models. However, Goshal (2005) convincingly argued, with supporting evidence, that agency theory is destroying good management practices, counterproductively promoting opportunistic behavior instead of cooperation. More recently, Bower and Paine (2017), in the Harvard Business Review, provide evidence showing that, contrary to agency theory's founding claim, shareholder-oriented governance is threatening economic efficiency. The fact that maximizing value for shareholders became an overriding objective of CEOs, backed by governments, led to practices and regulations about executive compensation, shareholders' rights, the power of boards, investors' behavior and management attitudes, that end up undermining innovation, misusing corporate assets, and under-investing in the future (Bower and Paine 2017; Cushen and Thompson 2016). In sum, shareholder-oriented governance is being denounced for damaging the corporation itself (along with society): managing to protect the interests of shareholders often conflicts with managing to protect the interest of the corporation. 


\section{About the political nature of incorporated firms}

Shareholder-oriented governance advocacy is a normative, not positive, claim, grounded on the theoretical (con)fusion between firms and corporations and the inferred assumption that the corporation's interests are aligned with those of shareholders. In fact, the "naturalization" of shareholder primacy is part of the liberal political project (Singer 2019; Weinstein 2012) already alluded to, a project that dismisses the political nature of firms/corporations. Indeed, by assuming that incorporated firms have only two constituent parties whose interests can be aligned, agency theorists are denying that firms embody conflicts of interests. The dismissal of the political dimension of firms is also what is at stake in the denial of authority and the exclusion of workers as a constitutive party: as emphasized by political scientists, authority is the very mark of the political (McMahon 1995); it is the basis of order in communities crossed by conflicting interests.

To the extent that incorporated firms are characterized by a type of conflictuality not solvable by expert opinion because it involves how power is ascribed and exercised by three constitutive parties endowed with partly antagonistic objectives, firms are political entities. In practice, the three parties are assigned differentiated rights by public regulations. Shareholder primacy implies giving shareholders ultimate control rights over the corporation. In the last decades, the protection of shareholders' rights increased significantly in all countries whereas the protection of workers' rights stabilized at best (Deakin et al 2018). Yet, since shareholders have limited liability - they are not accountable for the corporation's activities nor are they responsible to protect its interests - why are they attributed such control power? Conversely, since the role of directors and officers is, in strict legal terms, to act in the corporation's interest, why are they incentivized to serve shareholders' interests? Finally, since the efficiency of firms relies on their institutional ontology, which is grounded on workers' behaviour, as argued above, why are workers kept away from the exercise of power?

Answering these questions implies analytically and practically examining two fundamental issues: i) Who is legitimate to exercise power in incorporated firms; what is the legitimate structure of power relations? Ii) Which kind of institutional arrangements can legitimately best organize the coexistence of the conflicting parties (next section)?

Since the firm is here considered to be an organizational structure grounded on the acceptance by its members of a mutually cooperative scheme directed by authority, it is the legitimacy of the exercise of authority that must primarily be examined. According to empirical evidence, the perceived legitimacy of authority predominantly depends on procedural considerations. Specifically, it is judgments about whether decision-making procedures are perceived to be fair that prove to be the strongest and most consistent predictor of compliance with authority's directives (Crawshaw et al. 
2013). For example, the opportunity to voice one's view about assigned objectives results in higher acceptance and better performance (Tyler and Lind 1992).

If authority is consented because it helps members of a collective do better by complying, these members may find it legitimate to be entitled to check whether a mutually beneficial outcome really resulted. Further and most important, when "managerial authority is best regarded not as the authority of a principal over an agent but rather as authority that facilitates mutually beneficial cooperation among employees with divergent aims [...] there is a presumption that managerial authority should be democratically exercised by the employees" (McMahon 1994: iii). According to McMahon (1994: 133), the legitimation of authority requires a kind of workplace democracy defined as: "I regard democracy as reflexive authority, a way of exercising authority in which those who are subject to authority collectively determine the authoritative directives that will guide them". Which implies in practice that those under authority, i.e. workers at all hierarchical levels, should participate in the decisions (strategic and operational) the corporation needs to make, or elect the people who are to make them.

To be legitimate, managerial authority should be subject to appropriate forms of democratic control and the procedures used to take decisions and generate the authoritative directives should be participative. Specifically, it is not legitimate to keep workers out of the institutional arrangements that structure power relations within corporations, meaning that workers' interests should be considered along those of the two other constituent parties. Workers should be entitled to participate in business decisions and those who make decisions should be held accountable for the effects they have on workers (Anderson 2015). Industrial democracy, debated in the 1970s, but fallen into oblivion when neoliberalism took center stage, must be put again on the political agenda.

\section{NORMATIVE IMPLICATIONS FOR CORPORATE GOVERNANCE}

Extant corporate law is silent about how the interests of workers will/should be accommodated or how conflicts of interests are resolved. The workers' interests are supposed to be protected by contractual and regulatory means out of corporate law. When examining governance models other than shareholder primacy in the early 2000s, Hansmann and Kraakman (2000) asserted that he labour-oriented model, which involves employees in corporate governance by having them represented on the boards of directors, was definitely excluded as a realistic alternative governance form. This assertion is highly doubtful, though. In fact, Board-Level Employee Representation - BLER - is quite common within Europe: employee representatives make up at least $1 / 3$ of the board members in 11 countries and 36\% of European workers are represented on the boards (Favereau 2018); in fact, BLER is presently 
attracting much attention in policy circles ${ }^{10}$. However, there is indeed no economic argument that theoretically accounts for why this governance form happens to exist and persist - a very perplexing gap in the literature.

Our ontological claims provide theoretical arguments that help fill this gap: the nature of the firm, i.e. its ontology, is related to its efficiency and is constituted by two kind of institutions. One of these institutions (IAuth) provides the foundations for managerial power whose conditions of legitimacy suggest the adoption of a governance mode based on reflexive authority, i.e. a form of workplace/industrial democracy. This offers a theoretical grounding for BLER and more specifically for codetermination, defined as the presence of employee representatives on boards, with the same rights as shareholders representatives and at least one third of seats, plus the institution of plant-level works councils, composed of workers, with decision rights on work organization (Favereau, 2018). This kind of corporate governance is a way, certainly not unique, of operationalizing reflexive authority, a mode of firm governance that institutionally recognizes that work collectives, not principal-agent contracts, are the building blocks of firms. It acknowledges that corporations are composed of three parties and places authority, i.e. the productive collective purpose rather than shareholders' interests, at the center of corporate governance. Codetermination assumes that there is a radical conflict of interests between labor and capital and also that this conflict generates the need to organize coexistence institutionally; it represents a sophisticated and advanced way of managing cooperation, conflict and control in firms.

Codetermination exists in Germany (Mitbestimmung) and Scandinavian countries; BLER allows workers to participate in strategic decisions (relocation, offshoring, hiring and employment policy) and plant-level work councils (Betriebsrat) allow them to participate in operational decisions (work organization, working conditions) with managers. Codetermination establishes that managers must be formally considered as serving not only shareholders but the organization as a whole, and in particular, its efficient functioning for all input providers (investors and workers) in the long run. The importance of works councils as collective voice institutions should not be overlooked: experience shows that the most crucial factor for the success of employee participation is that it is not solely driven by top-down processes but emerges from the collectives of work. Whilst codetermination implies a weakening of the command and control structures, it does not eliminate managerial authority - in whose decisions employees now participate.

Codetermination can be regarded as a formally instituted acknowledgment of the deontic and political nature of corporations. It is a form of governance consistent with the ontology of firms, with

${ }^{10}$ https://www.vox.com/2018/8/15/17683022/elizabeth-warren-accountable-capitalism-corporations 
their being social entities grounded on two institutions (ICoop and IAuth) that involve two kinds of ethics. Rather than dictating substantive deontic obligations by which managers must abide, it establishes an institutional procedural design for deliberative and participative decision-making. Although Jensen and Meckling (1979) claimed that the fact that codetermination and industrial democracy seldom arise out of voluntary arrangements suggests that these governance modes are inefficient, in the last three decades a vast number of studies reveals that works councils are widely supported by employers (Mueller 2015; Paster 2012). Data collected by Paster (2012) shows that not only works councils but also BLER are institutional arrangements endorsed by executives and many firms, individually in contrast to most shareholders and most employers' federations who adopt a critical stance towards BLER.

Whilst codetermination remains underrated by most economists, it is seen as an opportune alternative by eminent political philosophers like Anderson (2015), who refuses to consider that shareholder primacy is undisputable and insists that corporations in democratic societies should be subject to as much scrutiny as that paid to the state. In her view, the state needs to supply the legal infrastructure required to facilitate cooperation in complex economies; it is thus the state that must establish the constitution of workplace governance through appropriate labour law and corporate law. Indeed, although foregoing developments concentrate on the latter, our ontological claims logically also involve the former. In a time where standard employment contracts are losing ground and digital platform workers are not directly subject to authority but nonetheless contribute to an entity's endeavour and economic outcomes, it is important that the required revision of employment law be informed by a proper theory of the firm.

It may rightly be objected that our "labor-oriented" governance proposal applies only to corporations, thus leaving governance in most firms unaddressed. But (giant) corporations' management practices spill over into the whole business world by virtue of becoming understood as best practices (Goshal, 2005). Statutory laws always end affecting expectations and beliefs, though certainly to different extents depending on prevailing contexts. A second valid objection is that for a normative shaping of social/power relations such as that embodied in codetermination to be effective, it must not depart too radically from the prevalent social and political context (Deakin 2017). Our conviction is that the generalization of codetermination, duly adapted to national circumstances, would progressively engender a shift in managers' worldview about the actual importance of work/workers (an importance utterly silenced in the agency theory/shareholder primacy decades); a shift, however weak, in how firms are governed would consequently ensue. 


\section{CONCLUSION}

The present paper begins by distinguishing the corporation (a legal form) from the firm (an economic entity) to specify that it is the latter that is subject to our social ontology inquiry. Since no collective productive economic purpose would ever be achieved without engaging work and more specifically social interactions while working, a key distinguishing feature of our study is to relate the social ontology of the firm with work. Our main aim is to identify ontological categories that can help building a pertinent theory of the firm, and deriving proper governance arrangements, a theory that definitely breaks with agency theory, its pervasive academic influence and barely disputed impact on corporate law.

The first step of our ontological inquiry consisted in arguing that firms are constituted by the acting in concert of actors whose interactions must be cooperative, which requires their being directed by authority, a noncoercive form of power involving subordination and embodied in organizational structures. Firms are thus viewed as structured cooperative endeavors, emergent entities ontologically irreducible to their composing elements. These entities exist by virtue of two distinct kinds of institutions that we consequently argue form the institutional ontology of the firm: i) cooperative norms (ICoop) that emerge, thanks to the human capacity for sympathy, from the interactions between workers and allow for horizontal cooperation and ii) compliance with authority norms (IAuth), related to constitutive rules that create "deontic powers", i.e. rights and obligations, that allow for vertical cooperation -cooperation between individual members and the organizational structure. Firms are then of a deontic ontological nature that, on one hand, explains the cohesiveness of the collective entity and its pursuing shared goals, and, on another hand, provides sources of efficiency distinct from that of price/market mechanisms, which explains why firms exist. Arguing this point was the second step of our ontological inquiry.

Deriving a theory of the firm, and inferring governance implications, from the foregoing ontological claims needs taking the legal form adopted by firms into account. The paper then turns to focus specifically on incorporated firms (corporations). A theory of the corporation is proposed as composed by three constitutive parties: shareholders, workers and organizational structures embodied by authority. The extent to which such theory departs from agency theory is emphasized. Finally, it is argued that the governance forms that are in line with the deontic ontology of the firm require being grounded on reflexive authority, a form of workplace democracy in which those under authority participate in determining the authoritative directives that will guide them. In terms of corporate law, one such governance form is codetermination, i.e. the presence of employee representatives in corporate 
boards and plant-level works councils. By providing an economic theoretical grounding of codetermination - and industrial democracy more broadly -, the paper contributes to fill a perplexing gap in the economics of the firm literature. It also breaks with the taboo related with the management issue in many heterodox trends of literature.

We are aware that many of the claims advanced in the paper definitely call for further grounding and theoretical elaboration. Our focus was on attempting to offer an encompassing picture of the range of issues involved in a theory of the firm and its governance, an aim engaged in at the detriment of more in-depth analyses. We hope that the present paper contributes to changing the representation of the firm in economic theory; the role of (collective) work and of the deontic dispositions of workers in the firm needs be finally duly acknowledged.

\section{REFERENCES}

ALCHIAN A. and Demsetz H. (1972). Production, information costs and economic organization. American Economic Review, LXII(2): 777-79.

ANDERSON, E. (2015), Liberty, Equality and Private Government, The Tanner Lectures in Human Values. Princeton University, https://tannerlectures.utah.edu/Anderson\%20manuscript.pdf

ARMOUR J. (2005). The proprietary foundations of corporate law. ESCR Working Paper $n^{o} 299$, Center for Business Research, University of Cambridge.

BODIE M. (2012). The post-revolutionary period in corporate law. Seattle University Law Review, 35 : 1033-1059.

BOLINO M. and Grant A. (2016). The bright side of being prosocial at work and the dark side too. The Academy of Management Annals, pp. 1-72.

BOWER J. and Paine L. (2017). The error at the heart of corporate leadership. Harvard Business Review, 95(3): 50-60.

CHASSAGNON, V. (2013). Towards a social ontology of the firm. Journal of Business Ethics, 124(2): 197-208.

COASE, R. (1937). The nature of the firm. Economica, 4(16): 386-405.

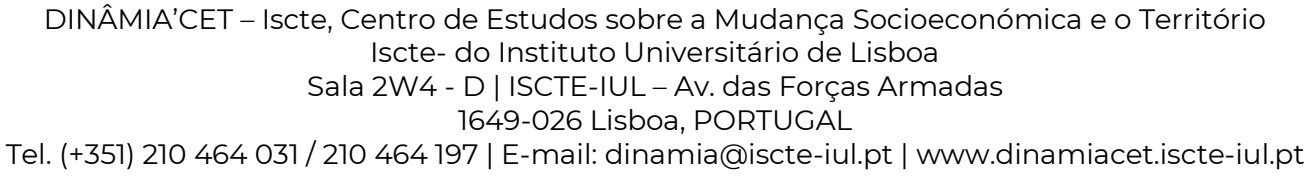


CRAWSHAW J., Cropanzano R., Bell C., Nadisic T. (2013). Organizational justice: New insights from behavioural ethics. Human Relations, 66(7): 885-904.

CUSHEN J. and Thompson P. (2016). Financialization and value: Why labour and the labour process still matter. Work, Employment and Society, 30(2): 352-365.

DEAKIN, S. (2017). Tony Lawson's theory of the corporation. Cambridge Journal of Economics, 41(5): 1505-1523.

DEAKIN, S., Sarkar, P. and Siems, M. (2018). Is there a relationship between shareholder protection and stock market development? Journal of Law, Finance and Accounting, 3(1): 115-146.

DIDRY, C. (2019). Labor law as a base for firms' organization. Historical Social Research, 44(1): $212-$ 230.

FAMA, E. (1980). Agency problems and the theory of the firm. Journal of Political Economy, 88(2): 288-307.

FAVEREAU O. (2016). The impact of financialisation of the economy on enterprises and labour relations. Geneva: International Labour Organization.

FAVEREAU O. (2018). Rapport sur les modèles de gouvernance d'entreprise, report for the International Labour Organization, Geneva: International Labor Organization.

FOSS, N. and Stea, D. (2014). Putting a realistic theory of mind into agency theory. European Management Review, 11: 101-116.

GINDIS, D. (2009). From fictions and aggregates to real entities in the theory of the firm. Journal of Institutional Economics, 5: 25-43.

GOSHAL S. (2005). Bad management theories are destroying good management practices. Academy of management Learning and Education, 4(1): 75-91.

GRAHAM, J., Iyer, R., Nosek, B., Haidt, J., Koleva, S., Ditto, P. (2011). Mapping the moral domain. Journal of Personality and Social Psychology, 101(2): 366-385.

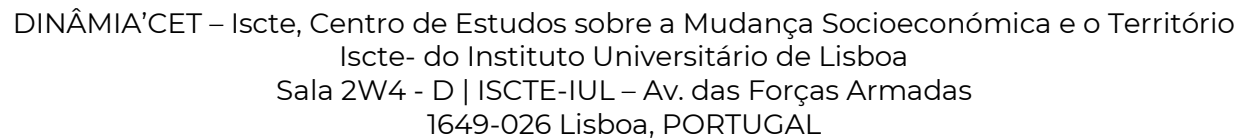


GREENFIELD K. (1998). The place of workers in corporate law. Boston College Law Review, 39(2): 283-327.

GUARNIERI, P. (2018). interactive intentionality and norm foundation. Journal of Institutional Economics, published on line: 21 December 2018: 1-15.

HANSMANN, H. and Kraakman, R. (2000). The end of history for corporate law. Yale Law School Working-Paper $n^{\circ} 235:$ 1-33.

HART O. (1989). An economist's perspective on the theory of the firm. Columbia Law Review, 89(7): $1757-1774$.

HODGSON, G. M. (2019). Taxonomic definitions in social science. Journal of Institutional Economics, 15(2): 207-233.

JENSEN M. and Meckling W. (1979). Rights and production functions: An application to labormanaged firms and codetermination. Journal of Business, 52(4): 469-506.

JENSEN M. and Meckling W. (1976). Theory of the firm: managerial behavior, agency costs and ownership structure. Journal of Financial Economics, 3(4): 305-60.

LAWSON, T. (2014). The nature of the firm and the peculiarities of the corporation. Cambridge Journal of Economics, 39(1): 1-32.

LOPES H. (2018). The moral dimensions of the employment relationship - Institutional implications. Journal of Institutional Economics, 14(1): 103-125.

MARSHALL, A (1890), Principles of Political Economy, https://eet.pixelonline.org/files/etranslation/original/Marshall,\%20Principles\%20of\%20Economics.pdf

MARTINS, N. O. (2018). An ontology of power and leadership. Journal for the Theory of Social Behaviour, 48(1): 83-97.

MARTINS, N. O. (2009). Rules, social ontology and collective identity. Journal for the Theory of Social Behaviour, 39(3): 323-344.

MCMAHON C. (1994, reed. 2017). Authority and democracy. Princeton: Princeton University Press.

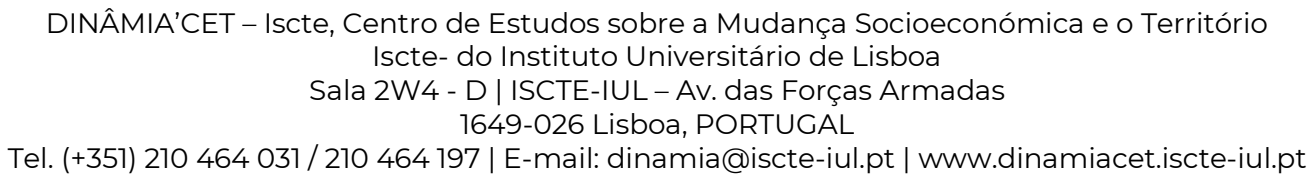


MCMAHON C. (1995). The political theory of organizations and business ethics. Philosophy and Public Affairs, 24(4): 292-313.

MUELLER S. (2015). Works councils and labor productivity: looking beyond the mean. British Journal of Industrial Relations, 53(2): 308-325.

PASTER, T. (2012). Do German employers support board-level codetermination? Socio-Economic Review, 10(3): 471-495.

RAZ J. (2006). The problem of authority. Minnesota Law Review, 90: 1003-1044.

REBITZER, JB and Taylor, LJ (2011). Extrinsic rewards and intrinsic motives: standard and behavioural approaches to agency and labor markets. In: Ashenfelter, O. and Card, D, (eds) Handbook of Labor Economics. Amsterdam: North Holland.

RIZZOLATTI, G. and Graighero, L. (2005). Mirror neuron: a neurological approach to empathy, in Changeux JP et al. (ed.), Neurobiology of Human Values. Berlin: Springer, pp. 107-123.

SEARLE, J. (1995). The construction of social reality. London: Penguin.

SINGER, A. (2019). The Form of the Firm. Oxford: Oxford University Press.

SUGDEN, R. (2005). Fellow-feeling, in Gui, B and Sugden, R (ed.), Economics and social interactions. Cambridge: Cambridge University Press, pp. 52-75.

SHWEDER, R., Much, N., Mahapatra, M., Park, L. (1997). The Big Three of Morality, in Brandt A. and Rozin, P. (eds), Morality and Health. New-York: Routlegde, pp. 119-169.

TYLER Tom and Allan Lind, "A relational model of authority in groups", Advances in Experimental Social Psychology, 25(1992): 115-191.

WEINSTEIN, O. (2012). Firm, property and governance. Accounting, Economics and Law, 2(2), Article 2: 1-55.

ZAK P. and Barraza J. (2013). The neurobiology of collective action. Frontiers in Neuroscience, 7(2013): 1-9.

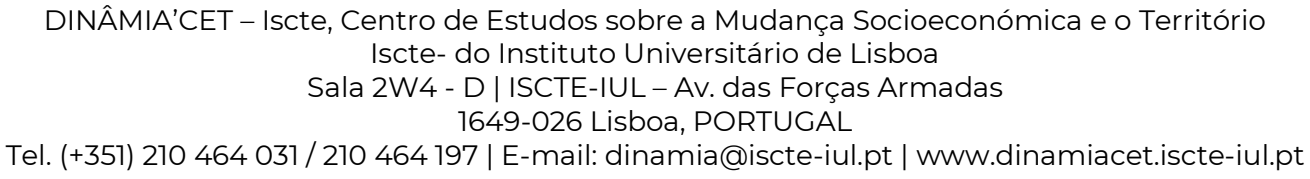

